\title{
Construction of a simple biocatalyst using psychrophilic bacterial cells and its application for efficient 3-hydroxypropionaldehyde production from glycerol
}

\author{
Takahisa Tajima*, Koji Fuki, Naoya Kataoka, Daizou Kudou, Yutaka Nakashimada and Junichi Kato
}

\begin{abstract}
Most whole cell biocatalysts have some problems with yields and productivities because of various metabolites produced as byproducts and limitations of substrate uptake. We propose a psychrophile-based simple biocatalyst for efficient bio-production using mesophilic enzymes expressed in psychrophilic Shewanella livingstonensis Ac10 cells whose basic metabolism was inactivated by heat treatment. The $45^{\circ} \mathrm{C}$ heat-treated cells expressing lac $Z$ showed maximum beta-galactosidase activity as well as chloroform/SDS-treated cells to increase membrane permeability. The fluorescent dye 5-cyano-2,3-ditolyl-tetrazolium chloride staining indicated that most basic metabolism of $A c 10$ was lost by heat treatment at $45^{\circ} \mathrm{C}$ for $10 \mathrm{~min}$. The simple biocatalyst was applied for 3-HPA production by using Klebsiella pneumoniae dhaB genes. 3-HPA was stoichiometrically produced with the complete consumption of glycerol at a high production rate of $8.85 \mathrm{mmol} 3-\mathrm{HPA} / \mathrm{g}$ dry cell/h. The amount of 3-HPA production increased by increasing the concentrations of biocatalyst and glycerol. Furthermore, it could convert biodiesel-derived crude glycerol to 3-HPA.
\end{abstract}

Keywords: Biocatalysis; Psychrophilic bacterium; 3-hydroxypropionaldehyde; Biomass

\section{Introduction}

Microorganisms are used as platform cell factories to produce various building block chemicals from renewable resources. The development of efficient microbial strains producing target compounds at high titers, yields, and productivities is required for industrial production. Metabolic engineering combined with systems biology has contributed to the enhanced production of chemicals and materials by redistributing and optimizing metabolic fluxes (Lee et al. 2011); however, this approach is often extremely laborious, costly, and difficult (Hodgman and Jewett 2012; Kwok 2010). On the other hand, thermostable enzymes expressed in Escherichia coli have achieved efficient bio-conversions with nearly $100 \%$ yields (Iwamoto et al. 2007; Ye et al. 2012). The process in the preparation of biocatalysts is easy and simple, which is briefly described

\footnotetext{
* Correspondence: ttajima@hiroshima-u.ac.jp Department of Molecular Biotechnology, Graduate School of Advanced Sciences of Matter, Hiroshima University, 1-3-1 Kagamiyama, Higashi-Hiroshima, Hiroshima 739-8530, Japan
}

as follows: thermostable enzymes are expressed in E. coli for designing synthetic pathways of chemicals production; the resulting cells are treated by heat typically at $70 \mathrm{C}$ for $30 \mathrm{~min}$ to inactivate the E. coli basic metabolism; finally the in vitro metabolic pathway is constructed to produce target compounds only by the activities of thermostable enzymes in the cells. The biocatalysts have succeeded in the efficient bio-conversions of lactate or malate from glucose with high yields because of the increase of the flux in the bioconversion pathway and the membrane permeability of substrate by heat treatment. This biocatalyst is called E. coli-based "simple biocatalyst".

We considered the construction of a simple biocatalyst using psychrophilic bacterial cells (psychrophile-based simple biocatalyst) instead of $E$. coli cells. This biocatalyst has significant advantages in the use of abundant mesophilic enzymes for designing bio-conversion pathways, in addition to thermostable enzymes because the use of psychrophilic hosts allows the heat treatment temperature for inactivation of basic metabolisms to be 
lower than that of $E$. coli based simple biocatalysts. Out of 2075 "completed and published" genome sequences in genome information database GOLD (http://www.genomesonline.org/; June, 7th, 2013), most genome sequences (1799 genomes; 86.7\%) belong to mesophilic organisms, while those in "hyperthermophile," "thermophile," or "thermotolerant" consist of only 232 genomes (11.2\%). Psychrophile-based simple biocatalysts may be able to exploit nearly all enzymes to produce chemicals. Furthermore, decreasing the heat treatment temperature to an ordinary temperature limits concerns about the excess disruption of the cellular structure and thermal decomposition of coenzymes, such as $\mathrm{NADP}^{+}$and NADPH, which are problems in E. coli-based simple biocatalysts (Ye et al. 2013).

In this study, the psychrophilic bacterium Shewanella livingstonensis Ac10 was selected as a host for the simple biocatalyst. Ac10 isolated from Antarctic sea shows optimum growth at $18^{\circ} \mathrm{C}$ but cannot grow above $30^{\circ} \mathrm{C}$ (Miyake et al. 2007). A gene expression system using the broad-host-range plasmid RSF1010 and its derivatives are available in Ac10, and proteins expressed at low temperatures have been revealed by proteomics analysis (Kawamoto et al. 2007; Kawamoto et al. 2009). We constructed the innovative psychrophile-based simple biocatalyst for efficient bio-conversion by recombinant mesophilic enzymes expressed in a psychrophilic bacterium S. livingstonensis Ac10 whose basic metabolism was inactivated by heat treatment. We evaluated the activity of recombinant $E$. coli $\beta$-galactosidase expressed in $S$. livingstonensis Ac10 and basic metabolism of Ac10 when cells were treated by heat, and applied it to the simple biocatalyst for 3-HPA production from glycerol by using
Klebsiella pneumoniae dhaB genes. Although the conversion from glycerol to 3-HPA is not multistep enzymatic reaction (pathway) but single step reaction, psychrophile-based simple biocatalyst will be applicable to in vitro metabolic pathway if it succeeds in efficient production.

\section{Materials and methods \\ Cell strains and growth conditions}

The bacterial strains and plasmids used in this study are described in Table 1. All E. coli strains were grown in Luria-Bertani liquid or solid agar medium at $37^{\circ} \mathrm{C}$ with $100 \mathrm{mg} / \mathrm{L}$ ampicillin when appropriate. S. livingstonensis Ac10-Rif ${ }^{r}$ (kindly provided by Prof. T. Kurihara in Kyoto University; Kawamoto et al. 2009) was grown with triptic soy broth (TSB; Difco Laboratories, Detroit, MI, USA) at $18^{\circ} \mathrm{C}$ with $50 \mathrm{mg} / \mathrm{L}$ rifampicin. E. coli $\mathrm{DH} 5 \alpha$ (TOYOBO, Japan) was used for the construction of the recombinant plasmids. Resulting plasmids were introduced into $S$. livingstonensis by transconjugation using E. coli S17-1 (Kawamoto et al. 2009). Transformed S. livingstrensis cells were selected using rifampicin and ampicillin at concentrations of $50 \mathrm{mg} / \mathrm{L}$ and $100 \mathrm{mg} / \mathrm{L}$, respectively. To overexpress $K$. pneumoniae glycerol dehydratase (DhaB) in S. livingstonensis Ac10-Rif $\mathrm{f}^{\mathrm{r}}$, dhaB genes were cloned into the vector pHA12 and expressed in Ac10Rif $^{\mathrm{r}}$ by $100 \mu \mathrm{M}$ IPTG induction. To prepare Ac10/ pHA12-dhaB cells for a resting cell reaction, Ac10-Rif / pHA12-dhaB cells grown overnight in TSB medium were inoculated into $100 \mathrm{~mL}$ of TSB culture medium (1\% inoculum). Cultures were incubated in Erlenmeyerflasks under constant agitation on a rotary shaker,

Table 1 Bacterial strains and plasmids used in this study

\begin{tabular}{|c|c|c|}
\hline Strains or plasmids & Relevant characteristics & Source or reference \\
\hline \multicolumn{3}{|l|}{ Strains } \\
\hline \multicolumn{3}{|l|}{ E. coli strains } \\
\hline $\mathrm{DH} 5 \mathrm{a}$ & $\begin{array}{l}\text { Cloning host supE44 } \Delta / a c U 169 \text { (\$80 lacZ } \Delta \mathrm{M} 15) \text { hsdR } \\
17 \text { recA1 endA1 gyrA96 thi-1 relA1 }\end{array}$ & TOYOBO \\
\hline S17-1 & recA pro hsdR RP4-2-Tc::Mu-Km::Tn7 & Simon et al. (1983) \\
\hline \multicolumn{3}{|l|}{ S. livingstonensis strains } \\
\hline Ac10-Rif ${ }^{r}$ & Parent strain, rifampin resistant mutant of Ac10 & Kawamoto et al. (2007) \\
\hline Ac10-Rif'/pHA10-lacZ & Ac10-Rif' harboring pHA10-lacZ & This study \\
\hline Ac10-Rif'/pHA12-dhaB & Ac10-Rif harboring pHA12-dhaB & This study \\
\hline K. pneumoniae T7 & 1,3-propanediol producing strain & Laboratory's stock \\
\hline \multicolumn{3}{|l|}{ Plasmids } \\
\hline pHA10 & Ampr, expression vector & Arai et al. (1991) \\
\hline $\mathrm{pHA} 12$ & Ampr, expression vector & Arai et al. (1991) \\
\hline pQF50 & Amp ${ }^{r}$, broad-host-range vector & Farinha and Kropinski (1990) \\
\hline pHA10-lacZ & Ampri, pHA10 containing lacZ & This study \\
\hline pHA12-dhaB & Ampr, pHA12 containing K. pneumoniae dhaB & This study \\
\hline
\end{tabular}


maintained at $120 \mathrm{rpm}$. Cell growth was recorded by measuring the optical density of the culture broth at $660 \mathrm{~nm}\left(\mathrm{OD}_{660}\right)$ and the dried weight of the cells. For the viability test of heat-treated cells, diluted samples were plated on TSB ager and cultured at $18^{\circ} \mathrm{C}$. After $3-$ 5 days the colonies were qualitatively observed.

\section{Plasmid construction}

Standard procedures for plasmid DNA preparation, restriction enzyme digestion, ligation, and transformation were used (Sambrook 1989). PCR reactions were performed with KOD plus Neo (Toyobo, Ohtsu, Japan) according to the manufacturer's recommendations. The E. coli lac $Z$ gene was amplified from pQF50 (Farinha and Kropinski 1990) by using primers lacZ_F (5'-AGAGGGTATTAATAATG AAAGGGAA-3') and lacZ_R (5' -CCCAAGCTTTGCCCG GTTATTATTATTTTTGA-3'). The PCR product was cloned between the SmaI and HindIII site of broad-host range expression vector pHA10 (Arai et al., 1991). The dhaB1, dhaB2, and dhaB3 genes (accession number AB859215) were amplified with ribosome binding site (GGAGA) from $K$. pneumoniae T7 genomic DNA using primers dhaB_F (5'-ATGCGAATTCGGAGAGATGAAC AATGAAAAGATCAAAACGA-3') and dhaB_R (5'-ATG CGGTACCTTAGCTTCCTTTACGCAGCT - $\left.3^{\prime}\right)$. The PCR fragment was ligated with EcoRI-KpnI digested pHA12 (Arai et al. 1991) to construct pHA12-dhaB.

\section{$\beta$-galactosidase activity}

For $\beta$-galactosidase assays, cells were harvested from aliquots of $1 \mathrm{~mL}$ of 24-h cultures of $S$. livingstonenesis $\left(\mathrm{OD}_{660}=0.5-1.0\right)$ by centrifugation and were washed twice with $0.9 \% \mathrm{NaCl}$. Bacterial pellets were resuspended in Z-buffer (36 mM NaH${ }_{2} \mathrm{PO}_{4}, 67 \mathrm{mM} \mathrm{Na} \mathrm{HPO}_{4}$, $0.1 \mathrm{mM} \mathrm{MgCl} 2,2 \mathrm{mM} \mathrm{MgSO}_{4}, 2.7 \mathrm{~mL} / \mathrm{l} \beta$-mercaptoethanol) before lysis with $20 \mu \mathrm{L}$ of chloroform and $10 \mu \mathrm{L}$ of $0.1 \%$ SDS by a Pasteur pipet or heat treatment. $\beta$ Galactosidase assays were performed at $37^{\circ} \mathrm{C}$ using the Miller protocol (Miller 1972) with modification. Briefly, $200 \mu \mathrm{L}$ of $4 \mathrm{mg} / \mathrm{mL}$ ONPG (Nacalai tesque, Kyoto, Japan) was added into $500 \mu \mathrm{L}$ of cell suspension, and the mixtures were incubated at $20^{\circ} \mathrm{C}$. After a 10 -min incubation, $250 \mu \mathrm{L}$ of stop buffer $\left(1 \mathrm{M} \mathrm{Na}_{2} \mathrm{CO}_{3}\right)$ was added, and the absorbance measured at $420 \mathrm{~nm}$ and $550 \mathrm{~nm}$. $\beta$-Galactosidase activities [Miller units (nmoles/ minute)] were calculated using the following formula (Miller 1972): $\beta$-Galactosidase activity (Miller units) = $\left(\mathrm{OD}_{420}-1.75 \times \mathrm{OD}_{550}\right) /\left(\mathrm{t} \times \mathrm{V} \times \mathrm{OD}_{660}\right) \times(1 / 0.0045) \times 1000$, where $\mathrm{t}=$ length of incubation $(\mathrm{min})$ and $\mathrm{V}=$ volume of culture used in the assay $(\mu \mathrm{L})$.

\section{CTC staining assay}

Cell viability was evaluated by CTC staining assay. A CTC (5-Cyano-2,3-ditolyl tetrazolium chloride) rapid staining kit for microscopy (Dojindo Laboratories, Kumamoto, Japan) was used for cell respiratory detection. CTC working solutions (final conc.: $50 \mathrm{mM}$ ) were prepared by dissolving CTC in $750 \mu \mathrm{L}$ sterilized distilled water. Triplicate 1-mL samples treated with $20 \mu \mathrm{L}$ of CTC solution and $5 \mu \mathrm{L}$ enhancing reagent B were incubated for $30 \mathrm{~min}$ at $18^{\circ} \mathrm{C}$. Stained cells were observed by inverted microscopy (E600 Eclipse, Nikon, Tokyo, Japan) equipped with blue excitation and red emission filters.

\section{3-HPA production}

Cultivated cells were collected by centrifugation $\left(4^{\circ} \mathrm{C}\right.$, $5 \mathrm{~min}, 3220 \times g$ ) and washed twice with $70 \mathrm{mM}$ potassium phosphate buffer ( $\mathrm{pH} 8.0)$. Reactions were started by the addition of glycerol, vitamin $\mathrm{B}_{12}(1.5 \mu \mathrm{M}$ in final concentration; Sigma-Aldrich Japan, Tokyo, Japan), and $50 \mathrm{mM} \mathrm{KCl}$ into the equal parts of the cell suspension. The reactions were carried out at $37^{\circ} \mathrm{C}$ and stopped by the addition of chloroform. Supernatant was obtained by centrifugation of the reaction mixture.

\section{Analytics}

Quantification of 3-hydroxypropionaldehyde (3-HPA) was based on the modified colorimetric method of Circle et al. (Circle et al. 1945). Briefly, $150 \mu \mathrm{L}$ of $10 \mathrm{mM}$ tryptophan dissolved in $0.05 \mathrm{~N} \mathrm{HCl}$ was mixed with $200 \mu \mathrm{L}$ of sample. After addition of $600 \mu \mathrm{L}$ of $37 \% \mathrm{HCl}$, the mixture was incubated at $37^{\circ} \mathrm{C}$ for $20 \mathrm{~min}$, and the absorbance was meadured at $560 \mathrm{~nm}$. Acrolein $(0-1 \mathrm{mM})$ was used for obtaining the standard curve. Glycerol was measured by a high performance liquid chromatograph system equipped with a UV detector and an ion exclusion column (RSpak KC-811, $8.0 \mathrm{~mm} \mathrm{ID} \times 300 \mathrm{~mm} \mathrm{~L}$; Shodex, Tokyo, Japan). The column was eluted at $60^{\circ} \mathrm{C}$ using $0.1 \%(\mathrm{v} / \mathrm{v})$ phosphate as a mobile phase at a flow rate of $0.7 \mathrm{~mL} / \mathrm{min}$.

\section{Results}

\section{Heat treatment condition for simple biocatalyst}

To evaluate the effect of heat treatment on S. livingstonenesis Ac10, we measured the $\beta$-galactosidase activity of the recombinant Ac10 cells in which the E. coli lacZ gene was expressed under the control of a tac promoter. Ac10-Rif $/$ pHA10-lacZ cells were pretreated with heat at $20-70^{\circ} \mathrm{C}$ for $10 \mathrm{~min}$. The cells lost viability when treated over $30^{\circ} \mathrm{C}$ (Figure 1 ). The $\beta$-galactosidase activity at $20^{\circ} \mathrm{C}$ in the heat-treated cells or chloroform/SDS-treated cells was measured by a standard protocol (Figure 1). Heat treatment at $20-45^{\circ} \mathrm{C}$ resulted in an increase in the $\beta$ galactosidase activity along with the increase of treatment temperature. The highest activity was obtained in the cells with heat treatment at $45^{\circ} \mathrm{C}$ as well as those with chloroform/SDS treatment which is generally used to permeabilize the cells. The supernatant suspension of 


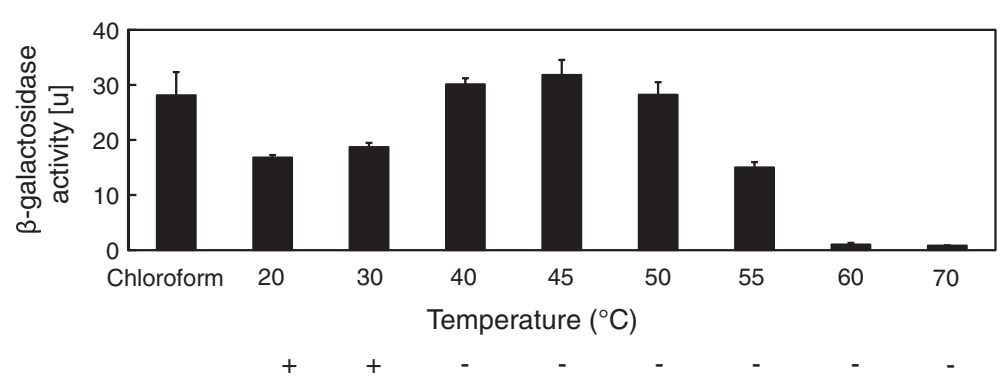

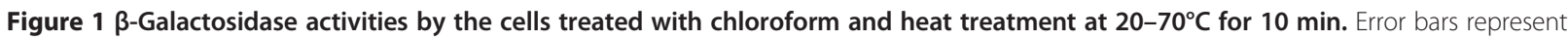
standard deviation of the mean $(n=3)$. Viabilities of heat-treated cells are indicated as " + " and "-".

cells heat-treated at $45^{\circ} \mathrm{C}$ had $14 \%$ residual $\beta$ galactosidase activity. On the other hand, cells heattreated above $45^{\circ} \mathrm{C}$ showed decreased $\beta$-galactosidase activity with the increase of temperature, and this activity was almost lost at $60^{\circ} \mathrm{C}$ and $70^{\circ} \mathrm{C}$. We carried out the CTC staining of cells treated for 5, 10, 15, and $30 \mathrm{~min}$ at $45^{\circ} \mathrm{C}$ to determine heat treatment time for the inactivation of basic metabolism in Ac10-Rif ${ }^{r}$ cells. CTC was converted to the insoluble fluorescent dye CTCformazan when CTC was reduced as an artificial redox partner instead of the final electron acceptor oxygen by respiring bacteria (Bovill et al. 1994). After CTC-staining, the 5-min heat-treated cells showed fluorescence with half intensity compared with that of non-treated reference cells (Figure 2). Fluorescence was scarcely detected in nearly all cells treated for more than $10 \mathrm{~min}$.

\section{3-HPA production by simple biocatalyst}

To apply the Ac10 simple biocatalyst to 3-HPA bioproduction, dhaB gene cluster containing dhaB1, dhaB2, and dhaB3 genes from $K$. pneumoniae T7 was cloned into a broad-host-range plasmid. Their amino acid sequences have $100 \%$ identities to corresponding genes in K. pneumoniae MGH 78578. Glycerol dehydratase, the gene product of $d h a B$, catalyzes conversion of glycerol to 3-HPA. At first, we failed to obtain any recombinant E. coli when the $d h a B$ cluster was introduced into $l a c I^{\mathrm{q}}$ less pHA10 plasmid containing a constitutive tac promoter. It seemed to be the result of the toxic effect of dhaB overexpression on $E$. coli cells. Therefore, we used pHA12 (Arai et al. 1991) that harbors lacl $^{\mathrm{q}}$ and its tac promoter controllable by the Lac repressor and isopropyl- $\beta$ - $D$-thiogalactopyranoside (IPTG) addition. By using pHA12, we succeeded the construction of the recombinant plasmid pHA12-dhaB for overexpression of the dhaB cluster. A transformant (Ac10-Rif $/$ pHA12dhaB) was obtained by introducing $\mathrm{pHA12-dhaB}$ into Ac10-Rif ${ }^{r}$. After Ac10-Rif $/$ pHA12-dhaB cells were treated by heat (at $45^{\circ} \mathrm{C}$ and for $15 \mathrm{~min}$ ), 3-HPA production was performed in phosphate buffer $\left(\mathrm{pH} \mathrm{8.0)}\right.$ at $37^{\circ} \mathrm{C}$ by the addition of $20 \mathrm{mM}$ glycerol, $10 \mu \mathrm{M}$ vitamin $\mathrm{B}_{12}$ and $50 \mathrm{mM} \mathrm{KCl}$ (final concentration) to cell suspension. 3-HPA was stoichiometrically produced with the complete consumption of glycerol within $30 \mathrm{~min}$ by Ac10-Rif $/ \mathrm{pHA} 12-\mathrm{dhaB}$ cells (5.57 g dry cell/L), while both glycerol consumption and 3-HPA production were not observed when the parent strain $\left(\right.$ Ac10-Rif $\left.{ }^{\mathrm{r}}\right)$ was used for the reaction (Figure 3A). Heat-treated Ac10-
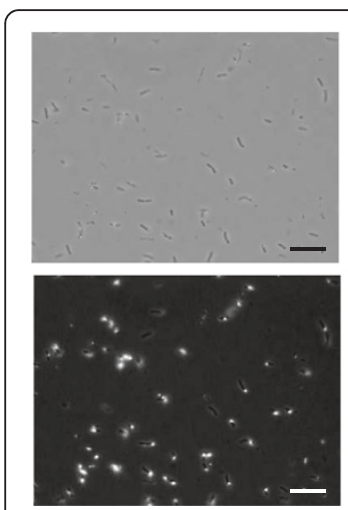

$0 \min$
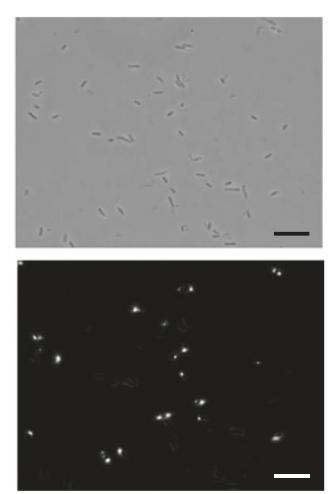

5
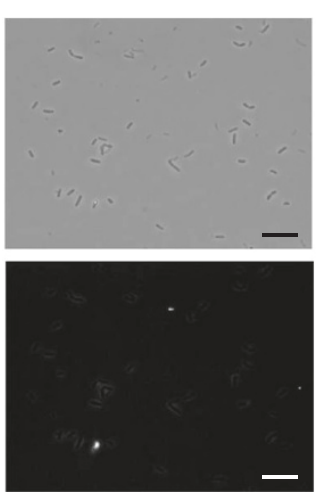

10
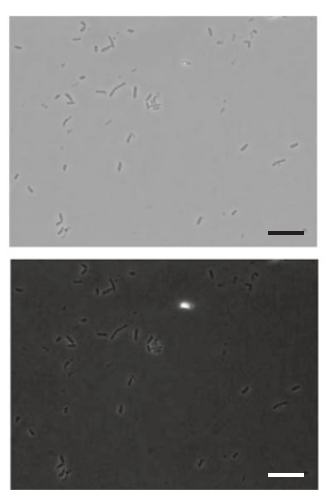

15

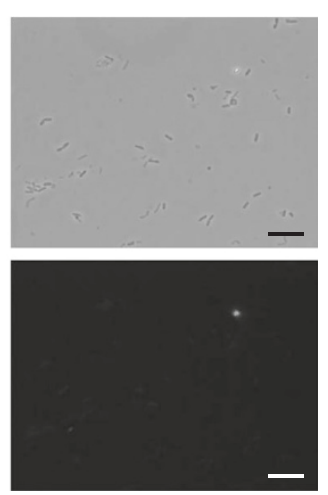

30

Figure 2 CTC staining cells heat-treated at $45^{\circ} \mathrm{C}$ for $\mathbf{0 , 5}, \mathbf{1 0}, \mathbf{1 5}$, and $30 \mathrm{~min}$. Phase-contrast micrographs (upper photos) and fluorescence micrographs (lower photos) of the same fields are shown. Bars represent $10 \mu \mathrm{m}$. 

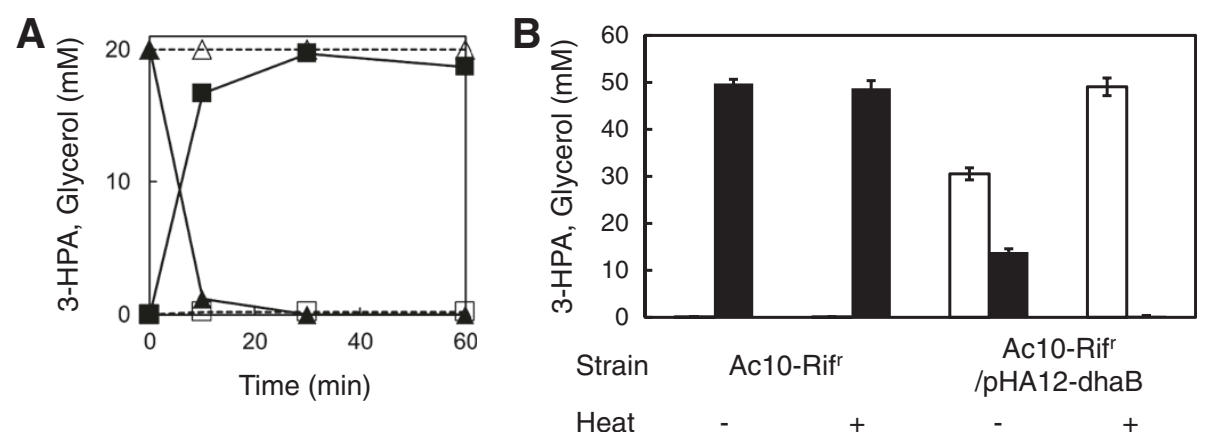

Figure 3 3-HPA production by simple biocatalyst. (A) Time course of 3-HPA production (squares) and glycerol consumption (triangles) from $20 \mathrm{mM}$ glycerol in the reaction by Ac10-Rif' (dashed line, open marker) and Ac10-Rif'/pHA12-dhaB (solid line, filled marker). (B) Concentration of 3-HPA (light) and glycerol (black) in the reaction by Ac10-Rif' and Ac10-Rif'/pHA12-dhaB cells with (+) or without (-) heat treatment. Error bars represent standard deviation of the mean $(n=3)$.

Rif $/$ pHA12-dhaB could completely convert $50 \mathrm{mM}$ glycerol to 3-HPA in $1 \mathrm{~h}$; however, the cells without heat treatment partially consumed glycerol $(35 \mathrm{mM})$ and produced only $31 \mathrm{mM} 3$-HPA (Figure 3B). The amount of 3-HPA produced increased with increasing concentrations of heat-treated cells and glycerol. 3-HPA production of $28.0 \mathrm{~g}$ dry cell/L from $300 \mathrm{mM}$ glycerol reached a high titer $(223 \pm 10.3 \mathrm{mM})$ with high productivity $(7.95 \mathrm{mmol} / \mathrm{g}$ dry cell/h). Although almost the same amount of 3-HPA $(225 \pm 6.5 \mathrm{mM})$ was produced from $400 \mathrm{mM}$ glycerol, the yield and productivity were decreased to 0.56 and 4.80 , respectively (Table 2 ).

Finally, we examined the simple biocatalyst for the ability to produce 3-HPA from crude glycerol. The crude glycerol used was waste derived from biodiesel production by an alkaline process in Thailand and consisted of $57.9 \%(\mathrm{w} / \mathrm{w})$ glycerol, $30.2 \%$ methanol, $12.5 \%$ fatty acids, and $2.7 \%$ ash. In the reaction mixture containing $64.3 \mathrm{mM}$ glycerol derived from a crude glycerol sample, Ac10-Rif $/ \mathrm{pHA} 12-\mathrm{dhaB}$ (45.7 g dry cell/L) could convert this to $63.5 \pm 5.96 \mathrm{mM} \mathrm{3-HPA}$ in $1 \mathrm{~h}$.

\section{Discussion}

In this study we constructed a simple biocatalyst for the production of value-added chemicals by using heattreated psychrophilic cells expressing mesophilic enzymes. The psychrophile-based simple biocatalyst showed that the membrane permeability of the substrate was increased by heat treatment at $45^{\circ} \mathrm{C}$ and most of the recombinant enzymes remained in the cells. Together with the CTC staining, heat treatment at $45^{\circ} \mathrm{C}$ for $10 \mathrm{~min}$ is adequate to inactivate the basic metabolism of Ac10. Thus, a psychrophilic-based simple biocatalyst can be constructed by using mostly mesophilic enzymes without inactivation by heat treatment. Therefore, we concluded that mesophilic enzymes can be used for a psychrophilic-based simple biocatalyst, and we could apply it to 3-HPA production from glycerol.

3 -HPA is a valuable compound used as a precursor for 1,3-propanediol (1,3-PDO), 3-propionic acid, and acrylic acid, which are useful for polymer production. 3-HPA is produced from glycerol by mesophilic bacteria, such as Lactobacullus reuteri, K. pneumoniae, Clostridium

Table 2 Production of 3-HPA from glycerol comparing to resting cell reactions of $L$. reuteri

\begin{tabular}{|c|c|c|c|c|c|c|}
\hline Strain & $\begin{array}{l}\text { Dry cell } \\
\text { weight (g/L) }\end{array}$ & $\begin{array}{l}\text { Glycerol } \\
(\mathrm{mM})\end{array}$ & $\begin{array}{l}\text { 3-HPA } \\
(\mathrm{mM})\end{array}$ & Yield & $\begin{array}{l}\text { Productivity } \\
\text { (mmol/g dry cell/h) }\end{array}$ & Reference \\
\hline \multirow[t]{3}{*}{ L. reuteri ATCC53608 } & $40-60$ & 200 & 160 & 0.80 & 4.27 & \multirow[t]{3}{*}{ Doleyres et al. 2005} \\
\hline & $\left(4.5 \times 10^{10}\right.$ & 400 & 235 & 0.59 & 6.27 & \\
\hline & $\times c f u / m L)$ & & & & & \\
\hline \multirow[t]{2}{*}{ L. reuteri CG001 } & 11.1 & 200 & 82 & 0.41 & 3.69 & \multirow[t]{2}{*}{ Chen et al. 2011} \\
\hline & 25.3 & 200 & 195 & 0.98 & 7.71 & \\
\hline \multirow[t]{5}{*}{ S. livingstonenesis Ac10-Rif'/pHA12-dhaB } & 5.57 & 50 & $49.3 \pm 1.9$ & 0.99 & 8.85 & \multirow[t]{5}{*}{ This study } \\
\hline & 9.48 & 200 & $82.9 \pm 1.0$ & 0.41 & 8.74 & \\
\hline & 19.52 & 200 & $142 \pm 1.7$ & 0.71 & 7.27 & \\
\hline & 28.03 & 300 & $223 \pm 10.3$ & 0.74 & 7.95 & \\
\hline & 46.86 & 400 & $225 \pm 6.5$ & 0.56 & 4.80 & \\
\hline
\end{tabular}


butyricum, Enterobacter agglomerans, and Citrobacter freudii (Vollenweider and Lacroix 2004). Some studies have reported the biological production of 3-HPA by extracted enzymes (Slininger et al. 1983) and whole cells of $K$. pneumoniae (Slininger and Bothast 1985) and $E$. agglomerans (Barbirato et al. 1996). However, 3-HPA is an intracellular intermediate and quickly reduced to 1,3PDO by a NADH-linked 1,3-PDO dehydrogenase in most 1,3-PDO native producers except for $L$. reuteri and some Lactobacillus strains, which are only the isolates shown to accumulate 3-HPA extracellularly. Barbirato et al. (1996) reported that 1,3-PDO native producers, such as K. pneumoniae and E. agglomerans, accumulated 17 to $30 \mathrm{mM}$ of 3-HPA into the cells and the yield of 3HPA production was very low $(<0.04)$. Enzymatic 3 -HPA production by glycerol dehydratase extracted from Lactobacillus sp. produced $95.8 \mathrm{mM}$ 3-HPA with consumption of $97.7 \mathrm{mM}$ glycerol (Slininger et al. 1983) and the yield was much higher (0.98). However, extractions of enzymes were costly and had handling difficulties for industrial applications. The simple biocatalyst is not only easy to be prepared and but also effective for 3-HPA production with high yield (0.99) and high productivity $(8.85 \mathrm{mmol} / \mathrm{g}$ dry cell $/ \mathrm{h}$ ) (Table 2$)$.

The productivity was still higher than any previously reported in the resting cell reaction of $L$. reuteri ATCC53608 (Doleyres et al. 2005) and its derivative mutant CG001 acclimatized in 3-HPA-containing medium (Chen et al. 2011) (Table 2), which was the only species shown to sustain large amounts of 3-HPA produced from glycerol (Vollenweider and Lacroix 2004). The titer of 3-HPA by our simple biocatalyst was almost the same as those by $L$. reuteri. We conducted the simple biocatalyst reaction at a cell density of $46.9 \mathrm{~g}$ dry cell/L and $400 \mathrm{mM}$ glycerol, but only $225 \mathrm{mM} 3$-HPA was produced. It is probably a result of the inhibitory effects of glycerol and 3-HPA on glycerol dehydratase (Doleyres et al. 2005). Glycerol deactivates glycerol dehydratase by the homolysis of the coenzyme upon binding to the apoenzyme (Toraya 2000). It can be overcome by ATPdependent reactivation factors in 1,3-PDO native producers (Toraya 2000). Although the simple biocatalyst did not have the reactivating system, 3-HPA yields in the reaction from high glycerol concentrations were only slightly lower than those of the $L$. reuteri strains (Table 2). Another type of DhaB in Clostridium butyricum (Raynaud et al. 2003), which does not require coenzyme vitamin $\mathrm{B}_{12}$ for its activity, may be an alternative for solution of the inhibitory effect by high concentrations of glycerol. Carbohydrazide can scavenge aqueous 3-HPA by forming hydrazone and its use was proposed to overcome the inhibitory effect of 3-HPA and to produce higher amounts of 3-HPA (Krauter et al. 2012). Although very high accumulation of 3-HPA scavenger- adduct $(2 \mathrm{M})$ in the medium was achieved by using a carbohydrazide scavenger, no methods are available now to recover 3-HPA from scavenger adducts. To apply the simple biocatalyst to industrial production of 3-HPA, measures for high cell-density immobilization and protection from toxic 3-HPA should be established.

The result of 3-HPA conversion from crude glycerol suggested that impurities in the crude glycerol sample did not affect the bio-conversion rate of the simple biocatalyst. The inhibitory effects of crude glycerol have been reported on cell growth (Venkataramanan et al. 2012) and cell viability (Gonzalez-Pajuelo et al. 2004), which resulted in decreased production of 1,3-PDO compared with that from pure glycerol. Because $S$. livingstonensis Ac10 cells are dead after heat treatment, the inhibitory effects of crude glycerol on "cell growth" and "cell viability" should not be of concern in the case of the simple biocatalyst, and it is one of its advantages. Taken together, the psychrophile-based simple biocatalyst is a useful and effective option for bio-production of valuable chemicals. For further improvement, the system for regeneration of cofactors, such as NAD (P) H and ATP, should be developed.

\section{Competing interests}

The authors declare that they have no competing interests.

\section{Acknowledgments}

We thank Professor Tatsuo Kurihara in Kyoto University for providing S. livingstonenesis Ac10-Rif'.

Received: 15 October 2013 Accepted: 3 December 2013

Published: 5 December 2013

\section{References}

Arai H, Igarashi Y, Kodama T (1991) Construction of novel expression vectors effective in pseudomonas cells. Agric Biol Chem 55(9):2431-2432

Barbirato F, Grivet JP, Soucaille P, Bories A (1996) 3-Hydroxypropionaldehyde, an inhibitory metabolite of glycerol fermentation to 1,3-propanediol by enterobacterial species. Appl Environ Microbiol 62(4):1448-1451

Bovill RA, Shallcross JA, Mackey BM (1994) Comparison of the fluorescent redox dye 5-cyano-2,3-ditolyltetrazolium chloride with p-iodonitrotetrazolium violet to detect metabolic activity in heat-stressed Listeria monocytogenes cells. J Appl Bacteriol 77(4):353-358

Chen G, Yang D, Xiao Y, Chen H (2011) Influence of conditions on reuterin accumulation by the resting cell biotransformation process. Chin J Chem Eng 19(6):1023-1027

Circle SJ, Stone L, Boruff CS (1945) Acrolein determination by means of tryptophane. Ind Eng Chem 17(4):259-262

Doleyres Y, Beck P, Vollenweider S, Lacroix C (2005) Production of 3hydroxypropionaldehyde using a two-step process with Lactobacillus reuteri. Appl Microbiol Biotechnol 68(4):467-474. 10.1007/s00253-005-1895-4

Farinha MA, Kropinski AM (1990) Construction of broad-host-range plasmid vectors for easy visible selection and analysis of promoters. J Bacteriol 172 (6):3496-3499

Gonzalez-Pajuelo M, Andrade JC, Vasconcelos I (2004) Production of 1,3propanediol by Clostridium butyricum VPI 3266 using a synthetic medium and raw glycerol. J Ind Microbiol Biotechnol 31(9):442-446. 10.1007/s10295-004-0168-z

Hodgman CE, Jewett MC (2012) Cell-free synthetic biology: thinking outside the cell. Metab Eng 14(3):261-269. 10.1016/j.ymben.2011.09.002

Iwamoto S, Motomura K, Shinoda Y, Urata M, Kato J, Takiguchi N, Ohtake H, Hirota R, Kuroda A (2007) Use of an Escherichia coli recombinant producing thermostable polyphosphate kinase as an ATP regenerator to produce 

AEM.00278-07

Kawamoto J, Kurihara T, Kitagawa M, Kato I, Esaki N (2007) Proteomic studies of an Antarctic cold-adapted bacterium, Shewanella livingstonensis Ac10, for global identification of cold-inducible proteins. Extremophiles 11(6):819-826. 10.1007/s00792-007-0098-6

Kawamoto J, Kurihara T, Yamamoto K, Nagayasu M, Tani Y, Mihara H, Hosokawa M, Baba T, Sato SB, Esaki N (2009) Eicosapentaenoic acid plays a beneficial role in membrane organization and cell division of a cold-adapted bacterium, Shewanella livingstonensis Ac10. J Bacteriol 191(2):632-640. 10.1128/JB.00881-08

Krauter H, Willke T, Vorlop KD (2012) Production of high amounts of 3hydroxypropionaldehyde from glycerol by Lactobacillus reuteri with strongly increased biocatalyst lifetime and productivity. N Biotechnol 29(2):211-217. 10.1016/j.nbt.2011.06.015

Kwok R (2010) Five hard truths for synthetic biology. Nature 463(7279):288-290. $10.1038 / 463288 a$

Lee JW, Kim TY, Jang YS, Choi S, Lee SY (2011) Systems metabolic engineering for chemicals and materials. Trends Biotechnol 29(8):370-378. 10.1016/j. tibtech.2011.04.001

Miller J (1972) Assay of $\beta$-galactosidase. Experiments in Molecular Genetics. Cold Spring Harbor Laboratory Press, New York, pp 352-355

Miyake R, Kawamoto J, Wei YL, Kitagawa M, Kato I, Kurihara T, Esaki N (2007) Construction of a low-temperature protein expression system using a cold-adapted bacterium, Shewanella sp. strain Ac10, as the host. Appl Environ Microbiol 73(15):4849-4856. 10.1128/AEM.00824-07

Raynaud C, Sarcabal P, Meynial-Salles I, Croux C, Soucaille P (2003) Molecular characterization of the 1,3-propanediol (1,3-PD) operon of Clostridium butyricum. Proc Natl Acad Sci U S A 100(9):5010-5015. 10.1073/pnas.0734105100

Sambrook J (1989) Molecular cloning: a laboratory manual, 2nd edition. Cold Spring Harbor Laboratory Press, New York

Slininger PJ, Bothast RJ (1985) Optimizing aerobic conversion of glycerol to 3-hydroxypropionaldehyde. Appl Environ Microbiol 50(6):1444-1450

Slininger PJ, Bothast RJ, Smiley KL (1983) Production of 3hydroxypropionaldehyde from glycerol. Appl Environ Microbiol 46(1):62-67

Toraya T (2000) Radical catalysis of B12 enzymes: structure, mechanism, inactivation, and reactivation of diol and glycerol dehydratases. Cell Mol Life Sci 57(1):106-127

Venkataramanan KP, Boatman JJ, Kurniawan Y, Taconi KA, Bothun GD, Scholz C (2012) Impact of impurities in biodiesel-derived crude glycerol on the fermentation by Clostridium pasteurianum ATCC 6013. Appl Microbiol Biotechnol 93(3):1325-1335. 10.1007/s00253-011-3766-5

Vollenweider S, Lacroix C (2004) 3-hydroxypropionaldehyde: applications and perspectives of biotechnological production. Appl Microbiol Biotechnol 64 (1):16-27. 10.1007/s00253-003-1497-y

Ye X, Honda K, Sakai T, Okano K, Omasa T, Hirota R, Kuroda A, Ohtake H (2012) Synthetic metabolic engineering-a novel, simple technology for designing a Chimeric metabolic pathway. Microb Cell Fact 11:120. 10.1186/1475-2859-11-120

Ye X, Honda K, Morimoto Y, Okano K, Ohtake H (2013) Direct conversion of glucose to malate by synthetic metabolic engineering. J Biotechnol 164 (1):34-40. 10.1016/j.jbiotec.2012.11.011

doi:10.1186/2191-0855-3-69

Cite this article as: Tajima et al:: Construction of a simple biocatalyst using psychrophilic bacterial cells and its application for efficient 3-hydroxypropionaldehyde production from glycerol. AMB Express 2013 3:69.

\section{Submit your manuscript to a SpringerOpen ${ }^{\circ}$ journal and benefit from:}

- Convenient online submission

- Rigorous peer review

- Immediate publication on acceptance

- Open access: articles freely available online

- High visibility within the field

- Retaining the copyright to your article

Submit your next manuscript at $\gg$ springeropen.com 